\title{
The Novel Application of Chiral a-Ethylphenyl Amine Tartaric Acid Salts- Cyanosilylation of Prochiral Aldehydes
}

\author{
Luo Mei", ${ }^{*}$, Zhang Jia $\mathrm{Hai}^{2}$, Yin $\mathrm{Hao}^{2}$, Sun $\mathrm{Jie}^{3}$ and Hu Ke Liang ${ }^{2}$ \\ ${ }^{1}$ Hefei University of Technology, Department of Chemical Engineering, Hefei, 230009, China \\ ${ }^{2}$ University of Science and Technology, Department of Chemistry, Hefei, 230009, China \\ ${ }^{3}$ Shanghai Institute of Organic Chemistry, Shanghai, 200032, China
}

\begin{abstract}
The $\alpha$-ethylphenylamine tartaric acid salts 1a-1d were synthesized from R-(+)/S-(-)- $\alpha$-ethylphenylamine by reacting with $(2 \mathrm{~S}, 3 \mathrm{~S})-(+) /(2 \mathrm{R}, 3 \mathrm{R})-(-)$ dihydrobutanedioic acid. They were used as the catalysts in cyanosilylation of prochiral aldehydes to give the corresponding cyanohydrin trimethylsilyl ethers in moderate conversion at room temperature.
\end{abstract}

Keywords: $\alpha$-ethylphenylamine tartaric acid salts, R-(+)/S-(-)- $\alpha$-ethylphenyl amine, $(2 \mathrm{~S}, 3 \mathrm{~S})-(+) /(2 \mathrm{R}, 3 \mathrm{R})-(-)$ dihydrobutanedioic acid, cyanosilylation of prochiral aldehydes, cyanohydrin trimethylsilyl ethers.

\section{INTRODUCTION}

Many chiral catalysts provide good catalysis for the cyanosilylation, including Al-O [1] Ti-N [2], Mg-N complexes [3], basic cinchona alkaloid [4] chiral oxazaborolidinium ions [5], thiourea catalysts [6], and chiral amino acid salts [7]. But the scope and limitation of this reaction often makes it difficult for large scale syntheses. For example, generally, asymmetric cyanosilylation must be conducted with very little acid or base. Furthermore, the yields for the cyanosilylation of prochiral ketones are less than for cyanosilylation of prochiral aldehydes. The reported asymmetric cyanosilylation reactions were all conducted with base catalysts or bi-functional catalysts which are not easily synthesized [8].

Metal-ligands as lewis acid catalysts have been used widely in organic reactions and polymerization [9-11]. Howerever Brøsted acids catalysts have not been reported up to date. In this paper we report for the first time, a novel application of chiral (R)-(+)/(S)-(-)- $\alpha$-ethylphenyl amine, $(2 \mathrm{~S}, 3 \mathrm{~S})-(+) /(2 \mathrm{R}, 3 \mathrm{R})-(-)$ dihydrobutanedioic acid salts $1 \mathrm{a}-1 \mathrm{~d}$, as well as well as several control experiments (with catalysts 1e-1h). The experiments demonstrate that enantiomerically pure compounds are required because $(\mathrm{R})-(+) /(\mathrm{S})-(-)-\alpha-$ ethylphenylamine-(d1)-dihydrobutanedioic acid and $( \pm)-\alpha-$ ethylphenylamine $\quad(2 \mathrm{~S}, 3 \mathrm{~S})-(+) /(2 \mathrm{R}, 3 \mathrm{R})-(-)$ dihydrobutanedioic acid as the catalysts in this reaction do not produced the desired effect (Table 2). Perhaps the reason has something to do with the quality of the catalyst, as catalysts $1 \mathrm{a}-1 \mathrm{~d}$ are easily purified by crystallization, but catalyst $\mathrm{s} 1 \mathrm{e}-1 \mathrm{~h}$ are not. Catalysts 1a-1d are the Brønsted acids, and they were synthesized from $\alpha$-ethylphenylamine reacted with $(2 \mathrm{~S}, 3 \mathrm{~S})$ $(+) /(2 \mathrm{R}, 3 \mathrm{R})-(-)$ dihydrobutanedioic acid in methanol (Fig. 1).

*Address correspondence to this author at the Hefei University of Technology, Department of Chemical Engineering, Hefei, 230009, China; Tel: +86-0551-2903073, 15055109138;

E-mails: luomei@pku.edu.cn,lmhh5523385@yahoo.cn
In addition, the crystal structure of $S(-)$ - $\alpha$-ethylphenylamine $(2 \mathrm{R}, 3 \mathrm{R})-(-)$ dihydrobutanedioic acid salt (Fig. 2) was obtained.

\section{EXPERIMENTAL SECTION}

\section{General Procedures}

All cyanosilylation reactions were monitored by thin layer chromatography using $0.25 \mathrm{~mm}$ E. Mercksilica gel coated glass plates (60F-254) using UV light to visualize the course of reaction. Flash column chromatography was performed using E. Merck siliga gel (60, particle size $0.02-$ $0.03 \mathrm{~mm}$ ). Chemical conversion were obtained by ${ }^{1} \mathrm{HNMR},{ }^{13} \mathrm{CNMR},{ }^{1} \mathrm{H}$ and ${ }^{13} \mathrm{C}$ NMR spectra were obtained using a Bruker AM-300, Bruker AM-400 spectrometer. The following abbreviations were used to designate chemical shiftmutiplicities: $\mathrm{s}=$ singlet, $\mathrm{d}=$ doublet, $\mathrm{t}=$ triplet, $\mathrm{m}$ $=$ multiplet, Infraredspectra were recorded on a Mattson Galaxy Series FTIR 3000 Spectrometer. High resolution mass spectra were obtained on Micro GCT-MS, Optical rotations were measured on WZZ-1 automatic polarimeter. The enantiomeric excess(ee) was determined by HPLC analysis, HPLC was performed on Beijing Chuangxin tonghang system consisting of the following :pump, UV, DAICEL CHIRACEL OD-H; mobile phase,hexane. R$(+) / \mathrm{S}(-)-\alpha$-ethylphenyl amine, $(2 \mathrm{R}, 3 \mathrm{R})-(-) /(2 \mathrm{~S}, 3 \mathrm{~S})-(+)-2,3-$ dihydroxy butane-dioic acid were bought from the Changzhou KeRuiDa corporation. $\mathrm{R}(+)$ - $\alpha$-ethylphenylamine $[\mathrm{a}]_{\mathrm{D}}{ }^{25}=$ $39.2^{\circ}\left(\mathrm{c}=0.64, \quad \mathrm{CH}_{3} \mathrm{OH}\right), \mathrm{S}(-)-\alpha$-ethylphenylamine $[\mathrm{a}]_{\mathrm{D}}{ }^{25}=-39.3^{\circ}$ $\left(\mathrm{c}=0.68, \mathrm{CH}_{3} \mathrm{OH}\right)$ and $(2 \mathrm{R}, 3 \mathrm{R})-(-)-2,3-$ dihydroxy butane-dioic acid $[\mathrm{a}]_{\mathrm{D}}^{25}=-14.8^{\circ}\left(\mathrm{c}=1.58, \mathrm{H}_{2} \mathrm{O}\right),(2 \mathrm{~S}, 3 \mathrm{~S})-(+)-2,3$-dihydroxy butane-dioic acid $[\mathrm{a}]_{\mathrm{D}}{ }^{25}=15.0^{\circ}\left(\mathrm{c}=1.43, \mathrm{H}_{2} \mathrm{O}\right)$, The srtucture was solved by direct methods and different Fourier map techniques by using Brucker SMART program, and refinement on $F^{2}$ was performed by full-matrix least-squares methods with anistropic displacement parameters for all nonhydrogen atoms, all hydrogen atoms were found by difference Fourier map techniques by using SHELXS-97 
<smiles>C[C@H](N)c1ccccc1</smiles><smiles>CC(C)c1ccc(C(O)C(O)C(=O)O)cc1</smiles><smiles>C[C@H](N)c1ccccc1</smiles>

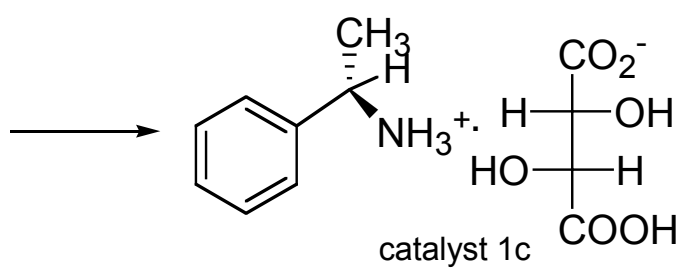<smiles>CC(N)c1ccccc1</smiles><smiles>CC(N)c1ccccc1</smiles><smiles>C[C@@H](N)c1ccccc1</smiles>

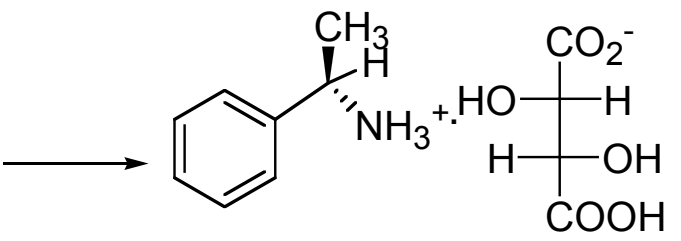
catalyst $1 \mathrm{~b}$<smiles>CC(N)c1ccccc1</smiles><smiles>O=C(O)C(O)C(O)C(=O)O</smiles><smiles>C[C@H](N)c1ccccc1</smiles><smiles>CC(N)([NH3+])c1ccccc1</smiles>

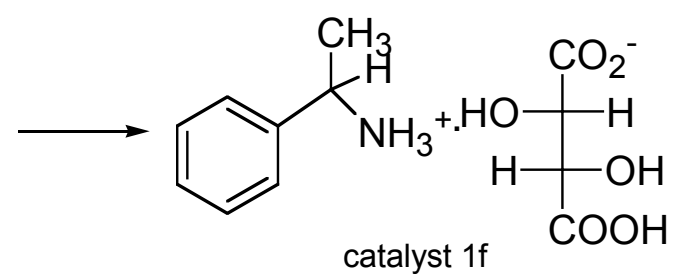<smiles>C[C@H](N)c1ccccc1</smiles><smiles>C[C@H](N)c1ccccc1</smiles>

+ dl tartaric acid

$\longrightarrow$ dihydroxybutanedioic acid salt

catalyst $1 \mathrm{~g}$

\section{S-(-)-|Áethylphenylamine-(dl)-2,3- dihydroxybutanedioic acid salt}

catalyst $1 \mathrm{~h}$

Catalyst 1a: R-(+)-|Áethylphenylamine-(2R,3R)-(-)-2,3-dihydroxybutanedioic acid salt Catalyst $1 \mathrm{~b}$ : R-(+)-|Áethylphenyllamine-(2S,3S)-(+)-2,3-dihydroxybutanedioic acid salt Catalyst 1c: S-(-)-|Áethylphenylamine-(2R,3R)-(-)-2,3-dihydroxybutanedioic acid salt Catalyst 1d: S-(-)-|Áethylphenylamine-(2S,3S)-(+)-2,3-dihydroxybutanedioic acid salt Catalyst 1e: (+-)-|Áethylphenylamine-(2R,3R)-(-)-2,3-dihydroxybutanedioic acid salt Catalyst 1f: (+-)-|Áethylphenylamine-(2S,3S)-(+)-2,3-dihydroxybutanedioic acid salt

Fig. (1). Synthetic routes of the catalysts1a-1h. 


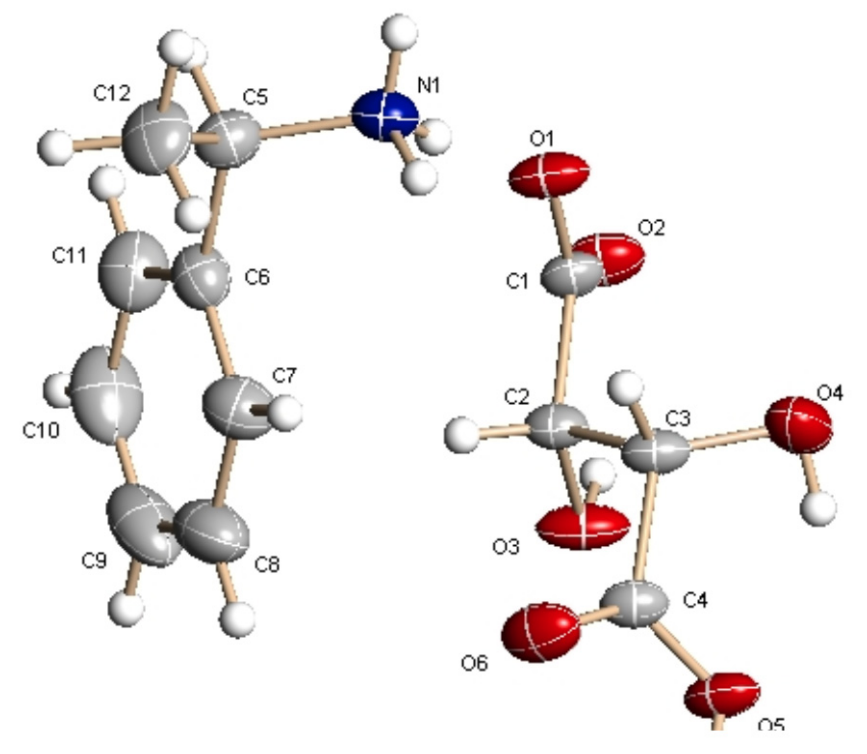

Fig. (2). Crystal structure of $1 \mathrm{c}$.

program and refined isotropically in the riding mode with fixed thermal factors. The final cycle of refinement gave rise to $\mathrm{R}=0.0331 \omega \mathrm{R}=0.0846, \mathrm{w}=1 /\left[\backslash \mathrm{s}^{\wedge} 2^{\wedge}\left(\mathrm{Fo}^{\wedge} 2^{\wedge}\right)+(0.0634 \mathrm{P})^{\wedge} 2^{\wedge}+\right.$ $0.0000 \mathrm{P}]$ where $\mathrm{P}=\left(\mathrm{Fo}^{\wedge} 2^{\wedge}+2 \mathrm{Fc}^{\wedge} 2^{\wedge}\right) / 3^{\prime}, \mathrm{s}=1.023,(\Delta / \sigma)_{\max }=0.000$ and $(\Delta / \sigma)_{\text {mean }}=0.000 .(\Delta / \rho)_{\max }=0.238,(\Delta / \rho)_{\min }=-0.167$. The molecular graphics were drawn with the Brucker SHELTXL program package $[12,13]$.

1a: Prepartion of R-(+)-a-Ethylphenyl Amine -(2R,3R)(-)-2,3-Dihydroxybutanedioic Acid Salt

$6.3 \mathrm{~g}$ of (-)tartaric acid was dissolved in $90 \mathrm{ml}$ methanol, and $5 \mathrm{~g}$ R-a-phenylethylamine was slowly added in a dry $250 \mathrm{ml}$ cone bottle, motionless above $24 \mathrm{~h}$, the single crystals were obtained $3.5 \mathrm{~g}, 31 \%$ in yield melting point: $66-68^{\circ} \mathrm{C}$, $[\mathrm{a}]_{\mathrm{D}}{ }^{25}=-$ $13.9^{\circ}\left(\mathrm{c}=1.72, \mathrm{CH}_{3} \mathrm{OH}\right) ;{ }^{1} \mathrm{HNMR}\left(300 \mathrm{MHz}, \mathrm{CD}_{3} \mathrm{OD}, 27^{\circ} \mathrm{C}\right)$, $\delta(\mathrm{ppm})=7.38 \sim 7.48(\mathrm{~m}, 5 \mathrm{H}), 4.89(\mathrm{~s}, 5 \mathrm{H}), 4.43 \sim 4.48(\mathrm{~m}, 1 \mathrm{H})$, $4.40(\mathrm{~s}, 2 \mathrm{H}), 1.62 \sim 1.64(\mathrm{~d}, \mathrm{~J}=5.16,3 \mathrm{H}),{ }^{13} \mathrm{CNMR}: 20.80(\mathrm{x} 2)$, 52.27,74.20,127.69,130.04,130.24,139.89,177.07,IR:3274,31 $93,2950,2867,2838,1710,1597,1436,1354,1309,165,1089,99$ 6,920,898,813,754,706,669,548,577,532; HRMS(EI): m/z(\%): calcd for $\mathrm{C}_{14} \mathrm{H}_{26} \mathrm{~N}_{2} \mathrm{O}: 271.1056$; found: 271.1053 .

1b: Prepartion of R-(+)- $\alpha$-Ethylphenyl Amine -(2S,3S)(+)-2,3-Dihydroxybutanedioic Acid Salt

The same procedure described $1 \mathrm{a},[\mathrm{a}]_{\mathrm{D}}{ }^{25}=13.6^{\circ}(\mathrm{c}=1.54$, $\left.\mathrm{CH}_{3} \mathrm{OH}\right)$.

1c: Preparation of S-(-)- $\alpha$-Ethylphenyl Amine -(2R,3R)-(-)2,3-Dihydroxybutanedioic Acid Salt

The same procedure described $1 \mathrm{a},[\mathrm{a}]_{\mathrm{D}}{ }^{25}=-13.5^{\circ}(\mathrm{c}=1.62$, $\left.\mathrm{CH}_{3} \mathrm{OH}\right)$

1d: Preparation of S-(-)- $\alpha$-Ethylphenyl Amine -(2S,3S)(+)-2,3-Dihydroxybutanedioic Acid Salt

The same procedure described $1 \mathrm{a},[\mathrm{a}]_{\mathrm{D}}{ }^{25}=+13.1^{\circ}(\mathrm{c}=1.42$, $\left.\mathrm{CH}_{3} \mathrm{OH}\right)$

1e: Preparation of $\alpha$-Ethylphenyl Amine -(2R,3R)-(-)-2,3Dihydroxybutanedioic Acid Salt

$6.3 \mathrm{~g}$ of (-)tartaric acid was dissolved in $90 \mathrm{ml}$ methanol, and $5 \mathrm{~g}$ a-ethylphenyl amine was slowly added in a dry
$250 \mathrm{ml}$ cone bottle, motionless above $0.5 \mathrm{~h}$, concentrated in vacuo, recrystallized with hexane, white solid was obtained $4.5 \mathrm{~g}$, melting point: $66-68^{\circ} \mathrm{C},[\mathrm{a}]_{\mathrm{D}}{ }^{25}=-15.2^{\circ}\left(\mathrm{c}=0.88, \mathrm{H}_{2} \mathrm{O}\right)$.

1f: Prepartion of $\alpha$-Ethylphenyl Amine-(2S,3S)-(+)-2,3Dihydroxybutanedioic Acid Salt

The same procedure described 1e, melting point: $66-68^{\circ} \mathrm{C},[\mathrm{a}]_{\mathrm{D}}{ }^{25}=15.4^{\circ}\left(\mathrm{c}=1.03, \mathrm{H}_{2} \mathrm{O}\right)$.

1g: Prepartion of R-(+)- $\alpha$-Ethylphenyl Amine-2,3Dihydroxybutanedioic Acid Salt

The same procedure described 1e, melting point: 64-66 ${ }^{\circ} \mathrm{C},[\mathrm{a}]_{\mathrm{D}}{ }^{25}=16.9^{\circ}\left(\mathrm{c}=0.8, \mathrm{H}_{2} \mathrm{O}\right)$.

1h: Preparation of S-(-)- $\alpha$-Ethylphenyl Amine-2,3Dihydroxybutanedioic Acid Salt

The same procedure described 1e, melting point: $68-70{ }^{\circ} \mathrm{C},[\mathrm{a}]_{\mathrm{D}}{ }^{25}=14.8^{\circ}\left(\mathrm{c}=0.8, \mathrm{H}_{2} \mathrm{O}\right)$.

1i: Preparation of R-(+)- $\alpha-($ Trimethylsilyoxyl)-Phenylacetonitrile

1a $0.15 \mathrm{~g}(0.55 \mathrm{mmol})$ was dissolved in $5 \mathrm{ml}$ hexane, benzaldehyde $0.2 \mathrm{ml} \quad(1.98 \mathrm{mmol})$ and TMSCN $(0.4$ $\mathrm{ml}, 3.00 \mathrm{mmol}$ )were successively added at room temperature. After $40 \mathrm{~h}$, the reaction were quenched. and the mixture was exacted with dichloromethane $(3 \times 10 \mathrm{ml})$, the combined organic layers was dried over $\mathrm{Na}_{2} \mathrm{SO}_{4}$, concentrated in vacuo, further purification was performed by silica gel (petroleum/dichloromethane 4/1).

The title compound was obtained as a colorless oil, conversion $=67 \%,{ }^{1} \mathrm{H}$ NMR $\left(300 \mathrm{MHz}, \mathrm{CDCl}_{3}\right) 7.56-7.59$ $(\mathrm{m}, 0.9 \mathrm{~Hz}, 2 \mathrm{H}), 7.31-7.34(\mathrm{~m}, 3 \mathrm{H}), 5.43(\mathrm{~s}, 1 \mathrm{H}), 0.16(\mathrm{~s}$, 9H). ${ }^{13} \mathrm{C} \quad \mathrm{NMR} \quad\left(75 \mathrm{MHz}, \mathrm{CDCl}_{3}\right)$ 136.1, 128.8(x2), 126.2(x2), 119.1, 63.5, -0.39(x3). HRMS(EI): m/z(\%):calcd for $\mathrm{C}_{11} \mathrm{H}_{15} \mathrm{NOSi}$ : 205.0923; found: 205.0922.

1j: R-(+)-2-(2-Furyl-Phenyl)-2-(Trimethylsilyloxy)Acetonitrile

The same prcedure described 1i, the title compound was obtained as a colorless oil, conversion $=78 \%, 1 \mathrm{H}$ NMR $\left(300 \mathrm{MHz}, \mathrm{CDCl}_{3}\right) 7.56-7.59(\mathrm{~m}, 0.9 \mathrm{~Hz}, 2 \mathrm{H}), 7.31-7.34(\mathrm{~m}$ $3 \mathrm{H}), 5.43(\mathrm{~s}, 1 \mathrm{H}), 0.16(\mathrm{~s}, 9 \mathrm{H}) .{ }^{13} \mathrm{C} \mathrm{NMR}\left(75 \mathrm{MHz}, \mathrm{CDCl}_{3}\right)$ 136.1, 128.8(x2), 126.2(x2), 119.1, 63.5, $-0.39(\mathrm{x} 3)$. HRMS(EI):M-15/z calcd for $\mathrm{C}_{10} \mathrm{H}_{11} \mathrm{NOSiF}: 208.0594$, Found:205.0583

1k: R-(+)-2-(4-Methoxyphenyl)-2-(Trimethylsilyloxy)Acetonitrile

The same prcedure described $1 \mathrm{i}$, the title compound was obtained as a colorless oil, conversion $=34 \%,{ }^{1} \mathrm{HNMR}$ $\left(300 \mathrm{MHz}, \mathrm{CDCl}_{3}\right)$ 7.38-7.40 (m, 2H), 6.91-6.93 (m, 2H), 5.44(s, 1H), 3.81(s,3H), 0.21(s, 9H). ${ }^{13} \mathrm{C} \mathrm{NMR}(75 \mathrm{MHz}$, $\left.\mathrm{CDCl}_{3}\right) \quad 160.4,128.6,127.9,119.4,114.3,63.4,55.3,-0.45(\mathrm{x} 3)$, HRMS(EI):calcd for $\mathrm{C}_{12} \mathrm{H}_{17} \mathrm{NO}_{2} \mathrm{Si}: 235.1029$ Found: 235 . 1024.

11: R-(+)-2-(4-Methylphenyl)-2-(Trimethylsilyloxy)Acetonitrile

The same prcedure described 1e, the title compound was obtained as a colorless oil, conversion $=33 \%$, ${ }^{1} \mathrm{HNMR}$ $\left(300 \mathrm{MHz}, \mathrm{CDCl}_{3}\right)$ 7.37-7.39 (m, 2H), 7.21-7.24 (m, 2H), 
5.48(s, 1H),2.38(s,3H), 0.24(s, 9H). ${ }^{13} \mathrm{C}$ NMR $(75 \mathrm{MHz}$, CDCl3) 139.3,133.5,129.6,126.4,63.6,31.6,22.6,21.2,14.1,0.23(x3) HRMS(EI) calcd for $\mathrm{C}_{12} \mathrm{H}_{17} \mathrm{NOSi} 219.1079$, Found:219.1084

\section{1m: (+)-2-(Trimethylsilyloxy)Pentanenitrile}

The same prcedure described $1 \mathrm{i}$, the title compound was obtained as a colorless oil, conversion $=77 \%$, ${ }^{1} \mathrm{HNMR}$ $\left(300 \mathrm{MHz}, \mathrm{CDCl}_{3}\right) 4.35-4.39(\mathrm{t}, \mathrm{J}=0.042 \mathrm{~Hz}, 1 \mathrm{H}), 1.70-1.74$ $(\mathrm{m}, 2 \mathrm{H}), 1.43-1.49(\mathrm{~m}, 2 \mathrm{H}), 0.89-0.95(\mathrm{~m}, 3 \mathrm{H}), 0.17(\mathrm{~s}, 9 \mathrm{H}) .{ }^{13} \mathrm{C}$ NMR (75 MHz, $\mathrm{CDCl}_{3}$ ) 120.0,61.2,38.2,16.8,13.3,-0.50(x3). HRMS (EI): $\mathrm{m} / \mathrm{z}(\%)$ :calcd for $\mathrm{C}_{8} \mathrm{H}_{17} \mathrm{NOSi}$ : 171.1079 ; found: 171.1081 .

\section{RESULTS AND DISCUSSION}

Our initial catalyst screening was done in THF solvent with a $28 \%$ mol catalyst (1a-1d) loading condition. It was found that catalyst 1a showed relatively good reactivity (Table 1). The reason for catalyst loading at $28 \% \mathrm{~mol}$ is that it allowed the catalyst to be measured at a weight $(0.15 \mathrm{~g})$ that could be done accurately. In order to get higher conversion, we prolonged the reaction time. However, after several experiments, we also found that according to the molar ratio of benzaldehyde/TMSCN (1:1.5), even if the reaction time was prolonged to 5 days, the ${ }^{1}$ HNMR showed not much improvement in conversion. The reason is probably closely connected with the structure of the catalyst, and is more important if the catalyst is a brønsted acid. In fact, we were pleased to find that if $\alpha$-ethylphenyl amine was used, the conversion was $>99 \%$ within $24 \mathrm{~h}$.

\section{Table 1. Catalysts Effect ${ }^{\mathrm{a}}$}

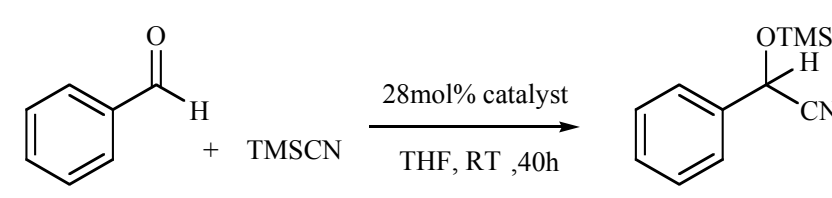

\begin{tabular}{|c|c|}
\hline Catalyst & Conv. $\%^{\mathrm{b}}$ \\
\hline 1a & 51 \\
\hline $1 \mathrm{~b}$ & 48 \\
\hline $1 \mathrm{c}$ & 44 \\
\hline 1d & 43 \\
\hline $1 \mathrm{e}$ & 20 \\
\hline 1f & 23 \\
\hline $1 \mathrm{~g}$ & 19 \\
\hline $1 \mathrm{~h}$ & 28 \\
\hline (R)-(+)/ $\alpha$-ethyl phenyl amine & 63 \\
\hline$(2 \mathrm{R}, 3 \mathrm{R})-(-)$ dihydrobutane dioic acid & 41 \\
\hline
\end{tabular}

${ }^{\mathrm{a}}$ The room temperature is around $10-20^{\circ} \mathrm{C},{ }^{\mathrm{b}} \mathrm{The}$ conversion (\%) was given by ${ }^{\mathrm{l}} \mathrm{HNMR}$ $\left(\mathrm{CDCl}_{3}\right)$.

Optimization of the solvents effects such as in hexane, ether, toluene, isopropanol, dichloromethane with $28 \mathrm{~mol} \%$ catalyst $1 \mathrm{a}$ and $1 \mathrm{~d}$, the results are summarized in Table $\mathbf{2}$, and hexane was the solvent of best choice, which gave the yield $67 \%$.
Table 2. Solvents Effect ${ }^{\mathrm{a}}$

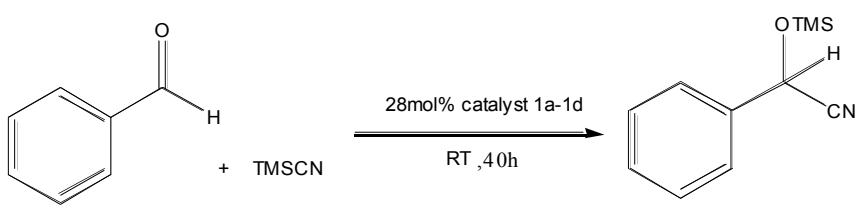

\begin{tabular}{|c|c|c|}
\hline Catalyst & Solvent & Conv. \% ${ }^{\text {b }}$ \\
\hline \hline 1a & $\mathrm{CH}_{2} \mathrm{Cl}_{2}$ & 48 \\
1a & Hexane & 67 \\
1a & Ether & 36 \\
1a & Isopropanol & 18 \\
1a & Toluene & 44 \\
1d & $\mathrm{CH}_{2} \mathrm{Cl}_{2}$ & 48 \\
1d & $\mathrm{Hexane}$ & 47 \\
1d & Ether & 36 \\
1d & Isopropanol & 18 \\
\hline
\end{tabular}
$\left(\mathrm{CDCl}_{3}\right)$.

Table 3. Cyanosilylation of Aldehydes Catalyzed by 1a and $1 d^{a}$

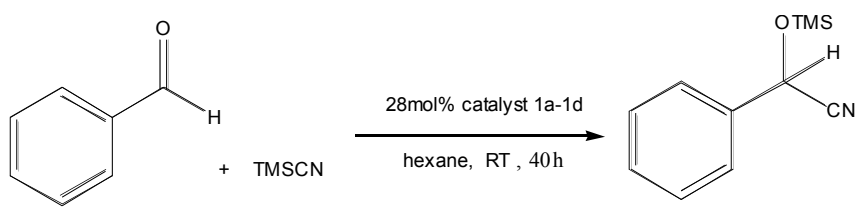

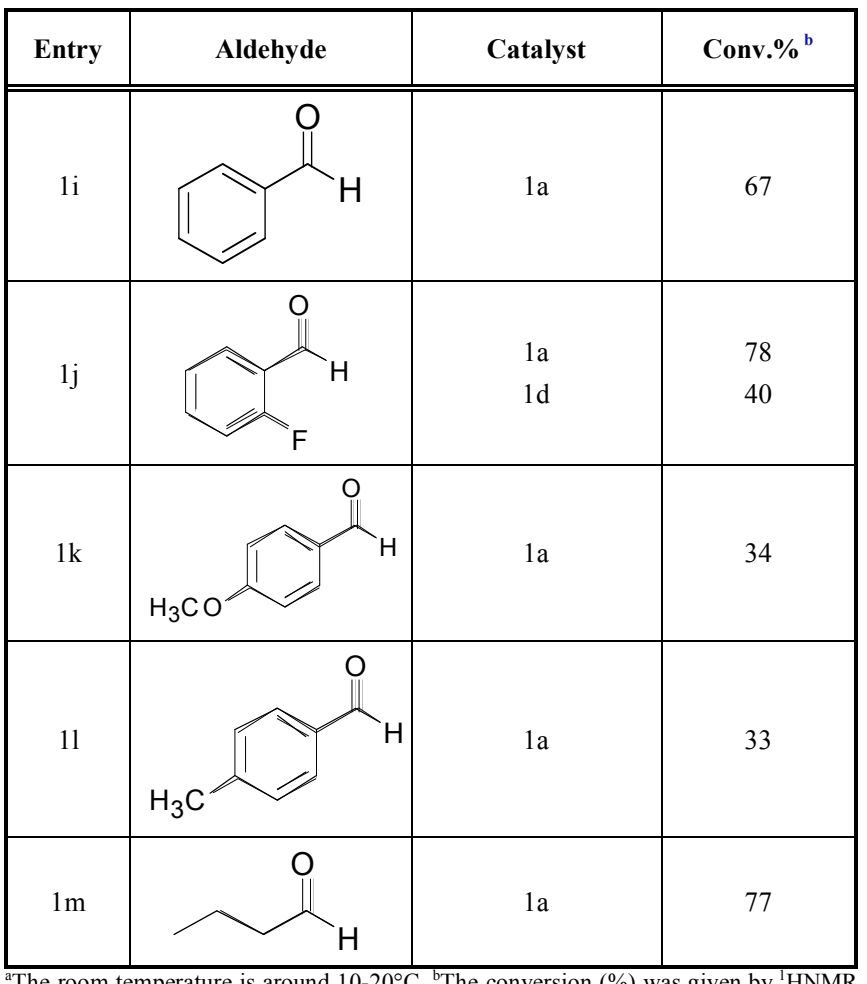

${ }^{\mathrm{a}}$ The room temperature is around $10-20^{\circ} \mathrm{C},{ }^{6}$ The conversion (\%) was given by ${ }^{\mathrm{T}} \mathrm{HNMR}$ $\left(\mathrm{CDCl}_{3}\right)$. 
Encouraged by the results achieved in the presence of 28 mol \% catalyst $1 \mathrm{a}$ in hexane at room temperature(around 10$20^{\circ} \mathrm{C}$ ), the asymmetric cyanosilylation of aromatic aliphatic aldehydes was also investigated under the optimized reaction conditions. After screening, we obtained some results with moderate to excellent enantioselectivity as displayed in Table 3. The aromatic aldehydes and aliphatic aldehydes such as 2-FPhCHO, 4- $\mathrm{OCH}_{3} \mathrm{PhCHO}, 4-\mathrm{CH}_{3} \mathrm{PhCHO}$, and $\mathrm{C}_{3} \mathrm{H}_{7} \mathrm{CHO}$ afforded the corresponding trimethylsilyl ethers in $78 \%, 34 \%, 33 \%$, and $77 \%$ conversion respectively. To further improve the conversion, we found that when the molar ratio of aldehyde to TMSCN was changed to $1: 5$, after 3 days, the conversions were nearly all $>99 \%$.

A probable reaction mechanism that can be proposed is that the proton acid can greatly active the $\mathrm{C}=\mathrm{O}$ bond, increasing the electronphilic reactivity of the carbon atom, which can then accept the nucleophilic attack of $\mathrm{CN}^{-}$.

\section{CONCLUSIONS}

In conclusion, the novel catalysts used in the cyanosilylation of prochiral aldehydes have been reported here for the first time with moderate yield and good enantioselectivity at room temperature. The use of these catalysts in other applications such as in Aldol reactions, the Henry ions, and allylation reactions are all in progress.

\section{REFERENCES}

[1] (a) Midland, M.; Lee, P. B. Asymmetric synthesis of hydroxycarboxylic acids. J. Org. Chem. 1981, 46, 3933-34. (b) Lang, T.; Li, D. Dynamic kinetic resolution via dual-function catalysis of modified cinchona alkaloids: asymmetric synthesis of $\alpha$-hydroxy carboxylic acids. J. Am. Chem. Soc. 2002, 124, 2870 71; (c) Jenkins S S. The Preparation and some properties of the chloromandelic acids, their Metal esters. J. Am. Chem. Soc. 1931, 53, 2341-43. (d) Strauss U.T.; Faber. K, Deracemization of ( \pm )mandelic acid using a lipase-mandelate racemase two-enzyme system. Tetrahedron:Asymmetry, 1999, 10, 4079-81.

[2] (a) Hiroshi, O.; Hideaki, N.; Kenzo, T.; Atsunori, M.; Shohei, I. A peptide-aluminum complex as a novel chiral Lewis acid. Asymmetric addition of cyanotrimethylsilane to aldehydes. J. Org. Chem. 1992, 57, 6778-83. (b) Hamashima, Y.; Sawada, D.; Kanai,
M.; Shibasaki, M. A new bifunctional asymmetric catalysis: an efficient catalytic asymmetric cyanosilylation of aldehydes. $J$. Am. Chem. Soc. 1999, 121, 2641-42.

[3] (a) Belokon, Y. N.; Green, B.; Ikonnikov, N. S.; North, M. The asymmetric addition of trimethylsilyl cyanide to ketones catalysed by a bimetallic, chiral (salen)titanium complex. Tetrahedron Lett. 1999, 40, 8147-50. (b) Hamashima, Y.; Kanai, M.; Shibasaki, M. Catalytic enantioselective cyanosilylation of ketones. J. Am. Chem. Soc. 2000, 122, 7412-13. (c) Hamashima, Y.; Kanai, M.; Shibasaki, M. Catalytic enantioselective cyanosilylation of ketones: improvement of enantioselectivity and catalyst turn-over by ligand tuning. Tetrahedron Lett., 2001, 42, 691-94.

[4] Corey, E. J.;Wang, Z. Enantioselective conversion of aldehydes to cyanohydrins by a catalytic system with separate chiral binding sites for aldehyde and cyanide components. Tetrahedron Lett. 1993, 34, 4001-04.

[5] (a) Tian, S. K.; Deng, L. A Highly enantioselective chiral Lewis base-catalyzed asymmetric cyanation of ketones. J. Am. Chem. Soc. 2001, 123, 6195-96. (b)Tian, S. K.; Hong, R.; Deng, L. Catalytic Asymmetric Cyanosilylation of Ketones with Chiral Lewis Base. $J$. Am. Chem. Soc. 2003, 125, 9900-01

[6] (a) Ryu, D. H.; Corey, E. J. Highly enantioselective cyanosilylation of aldehydes catalyzed by a chiral oxazaborolidinium ion. $J$ Am. Chem. Soc. 2004, 126, 8106-8107.(b) Ryu, D. H.; Corey, E. J. Enantioselective cyanosilylation of ketones catalyzed by a chiral oxazaborolidinium ion. J. Am. Chem. Soc. 2005, 127, 5384-87.

[7] Fuerst, D. E.; Jacobsen, E. N. Thiourea-catalyzed enantioselective cyanosilylation of ketones. J. Am. Chem. Soc. 2005, 127, 8964-65.

[8] Liu, X.; Qin, B.; Zhou, X.; He, B.; Feng, X. Catalytic asymmetric cyanosilylation of ketones by a chiral amino acid salt. J. Am. Chem. Soc. 2005, 127, 12224-25.

[9] Qian, C.T.; Zhu, C.J.; Huang, T. S. Enantioselective trimethylsilylcyanation of aldehydes catalyzed by chiral lanthanoid alkoxides. J. Chem. Soc. Perkin Trans. 1, 1998, 2131-32.

[10] Zhang, J.; Wang, X.; Jin, G.-X. Polymerized metallocene catalysts and late transition metal catalysts for ethylene. polymerization. Coord. Chem. Rev.. 2006, 250, 95-109.

[11] Vougioukas, A.E.; Kagan, H. B. Lanthanides as lewis-acid catalysts in aldol addition,cyanohydrin -forming and oxirane ring opening reactions. Tetrahedron Lett. 1987, 28, 5513-16.

[12] G.M. Sheldrick, SHELXS-97, Program for X-ray Crystal Structure Solution; G"ottingen University: Germany, 1997; G.M. Sheldrick, SHELXL-97, Program for X-ray Crystal Structure Refinement; G"ottingen University: Germany, 1997.

[13] G. H. Stout, L. H. Jensen, X-Ray Structure Determination: a Practical Guide. MacMillan: New York, 1968. 